\title{
Perawatan Berbasis Komunitas untuk Senior di Kawasan Tradisional Hutong: White Pagoda sebagai Studi Kasus
}

\author{
Ayu Larasati ${ }^{1}$, \\ Universitas Pelita Harapan \\ Email: ayu.larasati@uph.edu
}

\begin{abstract}
Dua tipe perawatan senior di Cina yaitu perawatan berbasis keluarga dan institusi tidak dapat memenuhi kebutuhan akan jumlah tempat tidur dan fasilitas perawatan secara menyeluruh. Perawatan berbasis keluarga tidak memiliki fasilitas perawatan yang memadai dan institusi memaksa senior untuk pindah ke tempat baru sehingga memaksa mereka untuk memutus kontak dan beradaptasi dengan lingkungan baru. Untuk memenuhi kebutuhan akan jumlah tempat tidur dan fasilitas tanpa memindahkan senior dari lingkungan asalnya, maka perawatan berbasis komunitas menjadi pilihan alternatif. Perawatan tipe ini menggunakan sistem polisentris yang terdiri dari perawatan pusat (care center) dan penunjang (care stations) yang tersebar di kawasan tempat tinggal senior. Akan tetapi, penerapan sistem ini pada Kawasan Tradisional Hutong memiliki tantangan pada keterbatasan lahan. Oleh karena itu, penelitian ini bertujuan untuk mengidentifikasi lahan/plot yang memungkinkan untuk penempatan perawatan pusat dan penunjang. Metode untuk mengidentifikasi plot ini dilakukan dalam 3 tahap: 1 . Identifikasi jumlah kebutuhan tempat tidur senior, 2 . Identifikasi plot berdasarkan analisis kondisi eksisting dari status kepemilikan, fungsi, dan kapasitas jumlah tempat tidur yang dapat diakomodasi, 3. Menentukan perawatan pusat dan penunjang dari plot-plot terpilih berdasarkan kapasitas lahan. Melalui sistem polisentris ini, perawatan berbasis komunitas bertujuan untuk menyediakan seluruh kebutuhan perawatan tanpa memindahkan senior ke lingkungan baru.
\end{abstract}

Kata Kunci: Perawatan berbasis Komunitas, Senior, White Pagoda, Hutong, China

\section{PENDAHULUAN}

Saat ini Cina tengah menghadapi proses penuaan yang cepat. Dalam kurun waktu 3 tahun jumlah senior diproyeksikan meningkat dari 180 juta menjadi 220 juta orang. Di antara kota-kota di Cina, Beijing memiliki proses penuaan tercepat yaitu dalam kurun waktu 5 tahun jumlah senior di Cina meningkat dari $8 \%$ menjadi $10 \%$ sementara kota-kota lain membutuhkan waktu selama 15 tahun untuk mencapai jumlah presentase yang sama (Lei, 2012). Oleh karena itu, kebutuhan perawatan senior di Beijing secara spesifik semakin meningkat.

Namun, tipe perawatan berbasis keluarga dan institusi masih belum dapat menyediakan kebutuhan perawatan menyeluruh untuk senior. Meskipun perawatan berbasis keluarga dapat menyediakan tempat tidur (tinggal) bagi senior, tetapi tidak dapat mengakomodasi fasilitas perawatan lengkap bagi mereka. Hal ini disebabkan karena struktur keluarga dengan pola terbalik 4-2-1 (4 kakek-nenek, 2 ayah-ibu, dan 1 anak) menyebabkan kesulitan ekonomi bagi anak dewasa untuk merawat orang tua yang senior. Selain itu, perawatan tipe ini masih tergantung pada fasilitas kesehatan publik di luar residensial dan terbatasnya desain rumah yang memadai untuk kebutuhan senior. Berbeda dengan perawatan berbasis institusi (PBI) yang dapat menyediakan fasilitas perawatan lengkap mulai dari fasilitas tempat tinggal, kesehatan, rekreasi, dan administrasi, $\mathrm{PBI}$ cenderung 
menjadi komunitas yang terisolasi dan jauh dari keluarga atau lingkungan sebelumnya tempat senior tinggal. Lingkungan yang baru menyebabkan senior kehilangan kontak sosial dari kerabat dan orang-orang yang dikenalnya sehingga menimbulkan perasaan tidak nyaman dan aman. Dengan demikian, perawatan berbasis keluarga dan institusi tidak dapat menyediakan perawatan yang meliputi keseluruhan aspek fisik dan psikologis.

Sebaliknya, perawatan berbasis komunitas (PBK) menggunakan sistem polisentris yang terdiri dari perawatan pusat (care center) dan penunjang (care station). Pada setiap 5000 rumah tangga (15.000 orang) terdapat 1 buah perawatan pusat yang menyediakan minimum 8 jenis pelayanan untuk senior, penyandang cacat, dan anak-anak (Qingwen, 2005). Perawatan pusat ini menyediakan fasilitas tempat tinggal, kesehatan, rekreasi, administrasi dan pelayanan in-house berupa pengiriman makanan dan bantuan untuk menyelesaikan pekerjaan rumah ke rumahrumah senior. Selanjutnya, perawatan penunjang disediakan pada setiap 1000 rumah tangga dengan luas $30 \mathrm{~m}^{2}$ (Qingwen, 2005). Perawatan penunjang hanya menyediakan ruang tinggal dan rekreasi bagi para senior yang tinggal di tempat tersebut. Dengan demikian, perawatan pusat dan penunjang berkerja sama sebagai satu sistem polisentris untuk menyediakan kebutuhan perawatan bagi senior tanpa memindahkan mereka dari lingkungan asal.

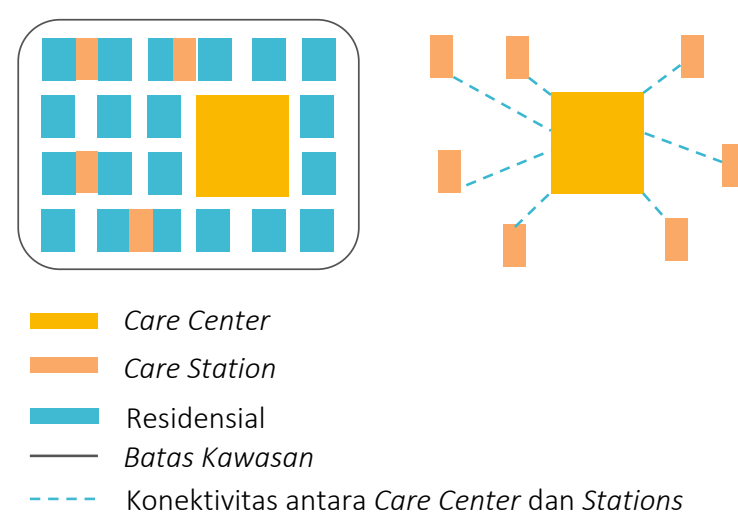

Gambar 1. Diagram Sistem Perawatan Berbasis Komunitas (Sumber: Ilustrasi dari Penulis)

Akan tetapi, penerapan PBK pada Kawasan Tradisional Hutong menghadapi tantangan berupa keterbatasan lahan. Sebagian besar Kawasan Hutong terdiri dari rumah tradisional (courtyard house) berlantai 1 dalam bentuk blok yang terdiri dari beberapa massa bangunan. Berkat modernisasi dan letak yang strategis di pusat kota, blok-blok tradisional ini tidak dapat menampung tingginya kepadatan populasi yang cepat (kurang dari standard 12 $\mathrm{m}^{2}$ per orang) sehingga menyebabkan timbulnya ruang informal tambahan di dalam blok (kualitas ruang tinggal yang buruk tanpa sirkulasi udara yang baik dan dimensi ruang yang tidak memadai) dan pembangunan baru yang mengeleminasi bangunan tradisional ini sehingga memaksa penghuni aslinya untuk pindah serta mengancam hilangnya budaya dalam kehidupan tradisional Beijing. Oleh karena itu, fungsi baru seperti PBK tidak dapat 
lagi mengeliminasi bangunan/blok tradisional sehingga perlunya identifikasi plot yang memungkinkan untuk dimasukan fungsi PBK tanpa mengeliminasi bangunan tradisional dan memaksa penghuninya untuk pindah ke lingkungan baru.

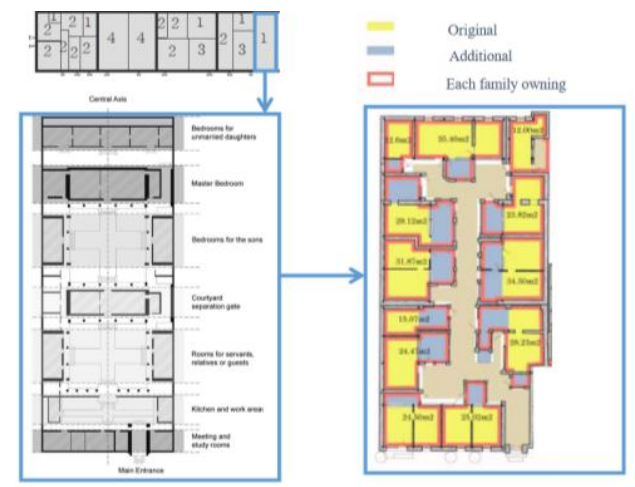

Gambar 2. Ruang Tambahan Informal pada Rumah Tradisional Hutong

(Sumber: Beijing Hutong Conservation Plan, 2002)

\section{METODE}

Berdasarkan permasalahan akan keterbatasan lahan, maka penelitian ini bertujuan mengidentifikasi plot pada Kawasan Hutong yang berpotensi dibangun perawatan pusat dan penunjang. Plot-plot berpotensi ini diidentifikasi melalui tiga tahap: 1. Identifikasi tapak yang sesuai dengan PBK, 2. Identifikasi jumlah tempat tidur yang harus disediakan, dan 3. Identifikasi plot berdasarkan analisis kondisi eksisting dari status kepemilikan, fungsi, dan kapasitas ruang tinggal yang dapat diakomodasinya. Setelah itu, perawatan pusat dan penunjang ditentukan berdasarkan kapasitas lahan dari plot-plot terpilih.
Pengumpulan data untuk identifikasi ini didapatkan dari hasil survey, studi kasus, dan studi pustaka. Selanjutnya, data-data ini distudi dan dianalisis untuk menentukan plotplot yang sesuai untuk PBK.

Pemilihan lokasi tapak mengikuti 3 kriteria yang sesuai untuk penerapan PBK. Kriteria pertama yaitu jumlah populasi yang sesuai untuk PBK minimal 5000 rumah tangga dengan rasio 1 keluarga terdiri dari 3 orang yaitu 15,000 orang. Kriteria kedua yaitu tapak merupakan kawasan tradisional yang dilindungi (preservasi) dan kriteria terakhir yaitu tapak memiliki batas/perimeter yang jelas sehingga penghuni komunitas senior yang dapat menerima fasilitas perawatan juga jelas. Berdasarkan ketiga kriteria ini, maka White Pagoda merupakan area yang cocok menjadi objek studi karena memenuhi ketiga kriteria tersebut. Kawasan ini memiliki 23,500 penduduk dan merupakan kawasan yang dilindungi serta memiliki batas perimeter kawasan yang jelas, yaitu keempat sisinya dilalui oleh jalan utama yang berhubungan langsung dengan subway.
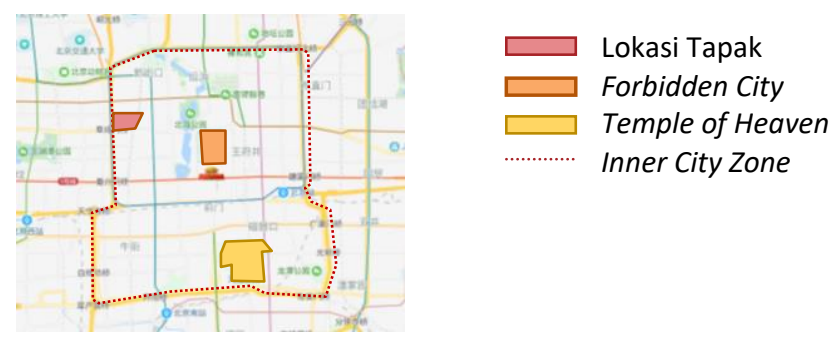

Gambar 3. Tapak Kawasan White Pagoda secara Makro (Sumber: http://baidu.map.cn) 

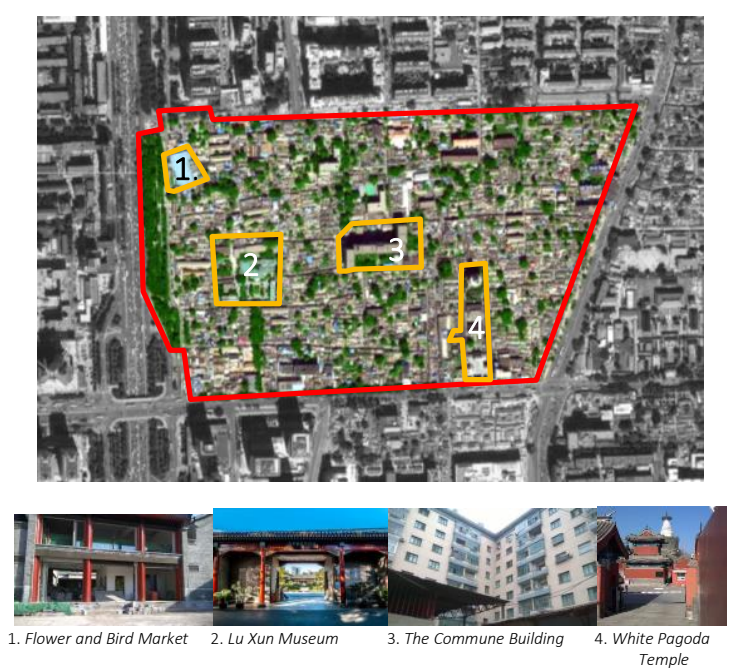

Gambar 4. Lokasi Tapak dan Nodes di Kawasan Tradisional White Pagoda

(Sumber: http://baidu.map.cn dan https://www.thebeijinger.com/category/blog-tags/lu-xunmuseum)

Setelah pemilihan lokasi tapak, jumlah tempat tidur senior yang perlu disediakan oleh PBK diidentifikasi untuk mengetahui kapasitas ruang yang perlu disediakan. Total populasi kawasan White Pagoda adalah 23,500 orang (berdasarkan Beijing Design Institute) dan jumlah senior ditentukan dengan menggunakan rasio $1: 5$ yaitu pada setiap 5 orang terdapat 1 orang senior. Rasio ini mengikuti perbandingan jumlah senior sebanyak 23,5\% dari total populasi Beijing atau 1/5 dari jumlah penduduk Beijing (Pinghui, 2016). Berdasarkan rasio ini, maka jumlah senior di Kawasan White Pagoda adalah 1/5 dari total yaitu 4.600 orang. Akan tetapi, jumlah senior yang menerima PBK ditentukan oleh rasio dari pemerintah yaitu 90:6:4 dengan pembagian $90 \%$ menerima perawatan berbasis keluarga, 6\% menerima PBK, dan $4 \%$ menerima perawatan berbasis institusi sehingga jumlah senior di White Pagoda yang menerima PBK berjumlah 276 orang (6\% dari 4.600 orang). Dengan demikian, PBK perlu menyediakan tempat tidur sebanyak 276 senior beserta fasilitas perawatannya, yaitu perawatan pusat dan penunjang yang menyediakan ruang tinggal, fasilitas medis, rekreasi, dan administrasi.

Setelah identifikasi jumlah senior, maka plotplot yang memungkinkan untuk mengakomodasi PBK ini diidentifikasi. Identifikasi plot-plot ini dilakukan dengan analisis kondisi eksisting yang meliputi aspek status kepemilikan (publik atau privat), fungsi (apakah fungsi eksisting sesuai dengan fungsi PBK), dan kapasitas ruang tinggal yang dapat diakomodasi oleh plot tersebut. Kapasitas ruang tinggal yang terdiri dari kamar tidur, kamar mandi, pantry, dan laundry ini diidentifikasi melalui unit ruang tinggal (modul) yang telah distudi dari beberapa proyek terbangun khusus untuk ruang tinggal senior.

Dari status kepemilikan, bangunan publik baru yang mengeliminasi bangunan tradisional memiliki potensi ruang untuk fungsi PBK. Hal ini disebabkan oleh dimensi blok bangunan baru ini lebih besar daripada dimensi blok bangunan tradisional yang berkisar antara $67 x$ $67 \mathrm{~m}$ hingga $100 \times 100 \mathrm{~m}$ sementara blok 
bangunan baru dapat mencapai $200 \times 200 \mathrm{~m}$ sehingga terdapat ruang-ruang antara yang memungkinkan untuk dimasukan fungsi PBK. Selain itu, bangunan publik langsung dikelola oleh pemerintah sehingga perijinan untuk perubahan atau renovasi relatif lebih mudah dan memiliki kepastian diikutinya standar pembangunan dari pemerintah yang berlaku saat itu. Namun, tidak hanya bangunan publik baru, tetapi bangunan residensial berstatus kepemilikan publik yang terbengkalai juga dapat digunakan kembali untuk fungsi baru yaitu PBK dengan menerapkan strategi adaptive reuse. Melalui strategi ini, bangunan tradisional yang terbengkalai dapat diperbaiki dan dipelihara untuk jangka panjang. Dengan demikian, berdasarkan status kepemilikan, terdapat 11 plot berstatus milik pemerintah yang memungkinkan untuk PBK yaitu Plot $A, B, C, D, E, F, G, H, I, J$, dan $K$ sebagaimana yang ditunjukan pada Gambar 5 .

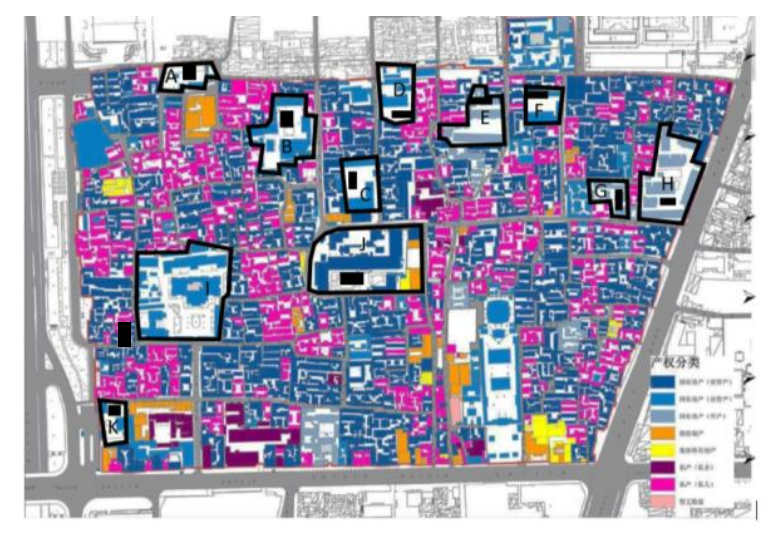

Gambar 5. Plot-plot Terpilih berdasarkan Status Kepemilikan (Sumber: Beijing Institute of Architectural Design, 2013)

Setelah status kepemilikan, fungsi eksisting memberikan pertimbangan apakah fungsi baru dapat menimbulkan konflik dengan fungsi eksisting atau tidak. Fungsi campuran ini mengikuti fungsi dari fasilitas PBK itu sendiri, yaitu residensial, medis, rekreasi, dan adminsitrasi/kantor. Dari kesebelas plot terpilih, terdapat 2 plot yang tidak sesuai dengan fungsi campuran PBK ini, yaitu Plot $B$ yang memiliki fungsi pendidikan atau sekolah dan Plot I yaitu museum (fungsi budaya). Dengan demikian, kedua plot ini dieliminasi sehingga tersisa 9 plot dari 11 plot terpilih.

Terakhir, plot terpilih harus dapat mengakomodasi tempat tidur bagi senior (276 orang). Identifikasi kapasitas ini dilakukan dengan menggunakan unit modular ruang tinggal yang mengikuti standar dimensi pemerintah Cina dan konfigurasi ruang dalamnya menyesuaikan dengan karakteristik senior yang sesuai dengan PBK yaitu senior mandiri atau senior yang mampu mengurus dirinya sendiri. Standar dimensi untuk ruang tinggal senior dari Pemerintah Cina terdiri dari 5 kategori jumlah tempat tidur yaitu 100 hingga 500 tempat tidur yang disertai oleh rasio berdasarkan fungsi fasilitasnya. Sesuai dengan jumlah tempat tidur yang perlu disediakan yaitu 276 tempat tidur maka kategori 200 tempat tidur yang diambil sebagai standar dimensi. Meskipun jumlah tempat tidur yaitu 276 buah sudah mendekati 300 buah tetapi kategori 200 dipilih karena rasio 
per fungsi lebih tinggi sehingga senior dipastikan mendapatkan kenyamanan yang lebih baik.

Selanjutnya, konfigurasi ruang yang sesuai dengan karakteristik senior mandiri didapatkan dari hasil studi beberapa studi kasus unit ruang tinggal senior pada proyek Kenyuen House for the Elderly di Wakayama, Jepang oleh Motoyasu Muramatsu, Handmaker Jewish Service for the Aging, dan Elderly House di Masan oleh Peter Zumthor. Dari studi kasus tersebut, unit ruang tinggal yang sesuai adalah unit ruang tinggal "sharedliving" yang berarti dalam satu unit dibagi oleh 2 senior yang memiliki tempat tidur sendiri (bila bukan pasangan) dan fasilitas lainnya seperti kamar mandi, laundry, dan pantry juga berbagi. Selain itu, untuk mendorong terciptanya interaksi sosial antar penghuni unit, fasilitas rekreasi yang terdiri dari ruang membaca, internet, catur, dan kaligrafi disediakan dan penempatannya diletakan di tengah-tengah unit sehingga akses pencapaiannya sama dan mudah dari seluruh unit yang ada. Tidak hanya dari studi kasus, tetapi merujuk pada pola simetri Rumah Tradisional Hutong, penempatan ini juga menyesuaikan dengan pola simetri dari Rumah Tradisional Hutong dimana ruang bersama diletakan ditengah dan diapit oleh ruang privat. Hal ini juga mempengaruhi jumlah unit ruang tinggal yang mengapit fasilitas rekreasi tersebut: untuk mempertahankan pola yang simetri, maka jumlah unit yang mengapit fasilitas bersama tersebut haruslah sama atau seimbang. Hal penting yang juga menjadi ciri khas dari rumah tradisional Hutong adalah courtyard atau halaman tengah yang berfungsi sebagai pusat kegiatan sosial bagi penghuninya dan identitas budaya masyarakat tradisional Beijing. Halaman tengah ini juga memiliki rasio efektif tinggi bangunan berbanding lebar halaman yaitu 1:3 (jika tinggi rumah $3 \mathrm{~m}$ maka lebar halaman minimal $9 \mathrm{~m}$ ) untuk memasukan sinar matahari pada musim dingin dan angin pada musim panas sehingga rasio ini menjadi pertimbangan dalam konfigurasi unit ruang tinggal secara utuh. Dengan demikian, unit ruang tinggal dari hasil studi baik studi kasus proyek maupun referensi rumah tradisional bagi senior berkarakteristik mandiri dapat dilihat pada Gambar 6 dan dimensinya pada Tabel 1.

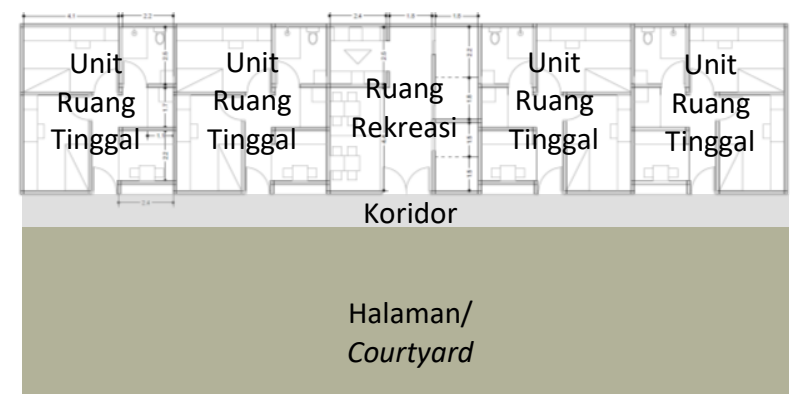

Gambar 6. Konfigurasi Ruang Unit Ruang Tinggal Senior PBK (Sumber: Ilustrasi dari Penulis) 
Tabel 1. Dimensi Standar Kategori 200 Tempat Tidur untuk 276 Tempat Tidur

(Sumber: Ministry of Civil Affairs of the People's Republic of China Architecture Standard of Elderly, 2010)

\begin{tabular}{ccccc}
\hline $\begin{array}{c}\text { Ruang } \\
\text { Tinggal }\end{array}$ & $\begin{array}{c}\text { Rasio } \\
\text { per } \\
\text { Orang } \\
\left(\mathbf{m}^{2}\right)\end{array}$ & $\begin{array}{c}\text { Jumlah } \\
\text { Orang }\end{array}$ & $\begin{array}{c}\text { Luas } \\
\text { Minimal } \\
\left(\mathbf{m}^{2}\right)\end{array}$ & $\begin{array}{c}\text { Total Luas } \\
\text { Ruang } \\
\text { Tinggal } \\
\left(\mathbf{m}^{2}\right)\end{array}$ \\
\hline K. Tidur & 11.4 & 1 & 11.4 & 11.4 \\
\hline K. Mandi & 0.38 & 2 & 0.76 & 5.5 \\
\hline $\begin{array}{c}\text { T.Cuci } \\
\text { Baju }\end{array}$ & 0.9 & 2 & 1.8 & 1.87 \\
\hline Dapur & 0.74 & $6 / 8$ & $4.44 / 5.92$ & 6 \\
\hline R.Makan & 0.74 & $6 / 8$ & $4.44 / 5.92$ & 10.56 \\
\hline
\end{tabular}

Berdasarkan konfigurasi ruang ini, maka kesembilan plot terpilih mampu mengakomodasi ruang tinggal bagi senior dengan kapasitas yang berbeda-beda. Kapasitas yang berbeda-beda ini ditunjukan pada Tabel 2. di bawah ini:

Tabel 2. Kapasitas Tempat Tidur yang Dapat Diakomodasi oleh Masing-masing Plot Terpilih

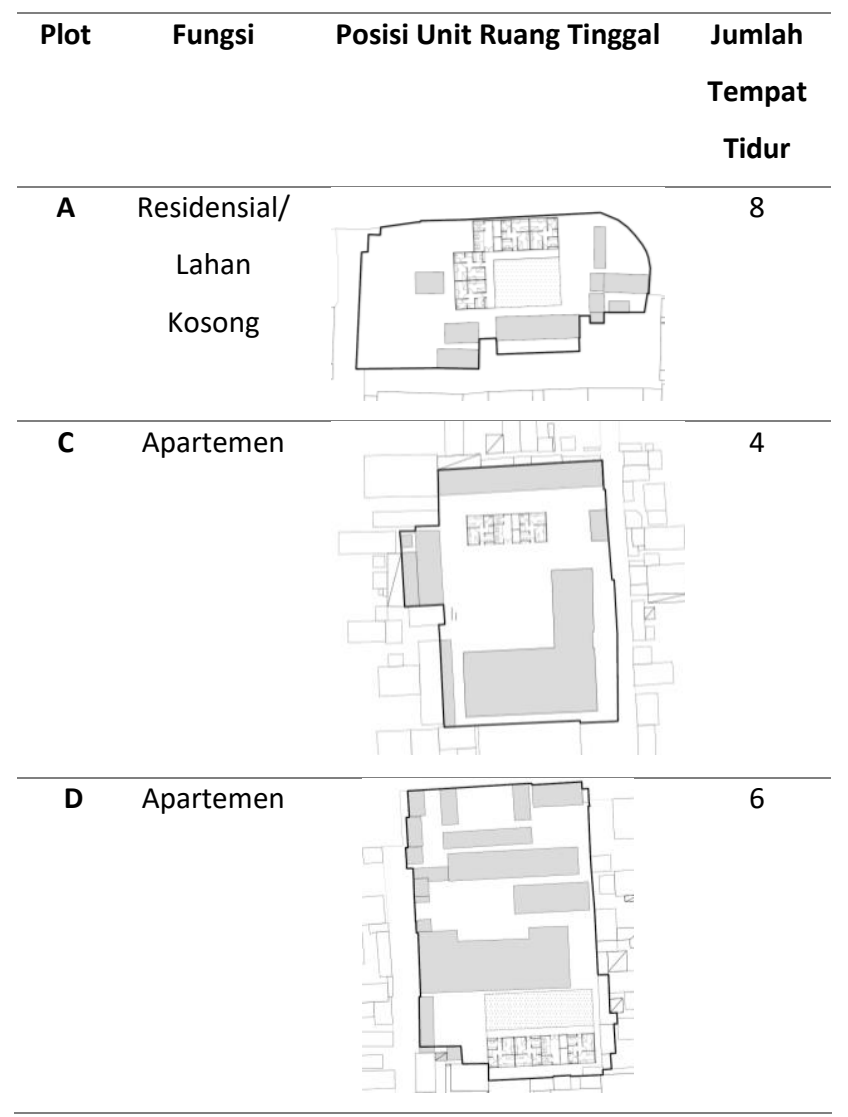

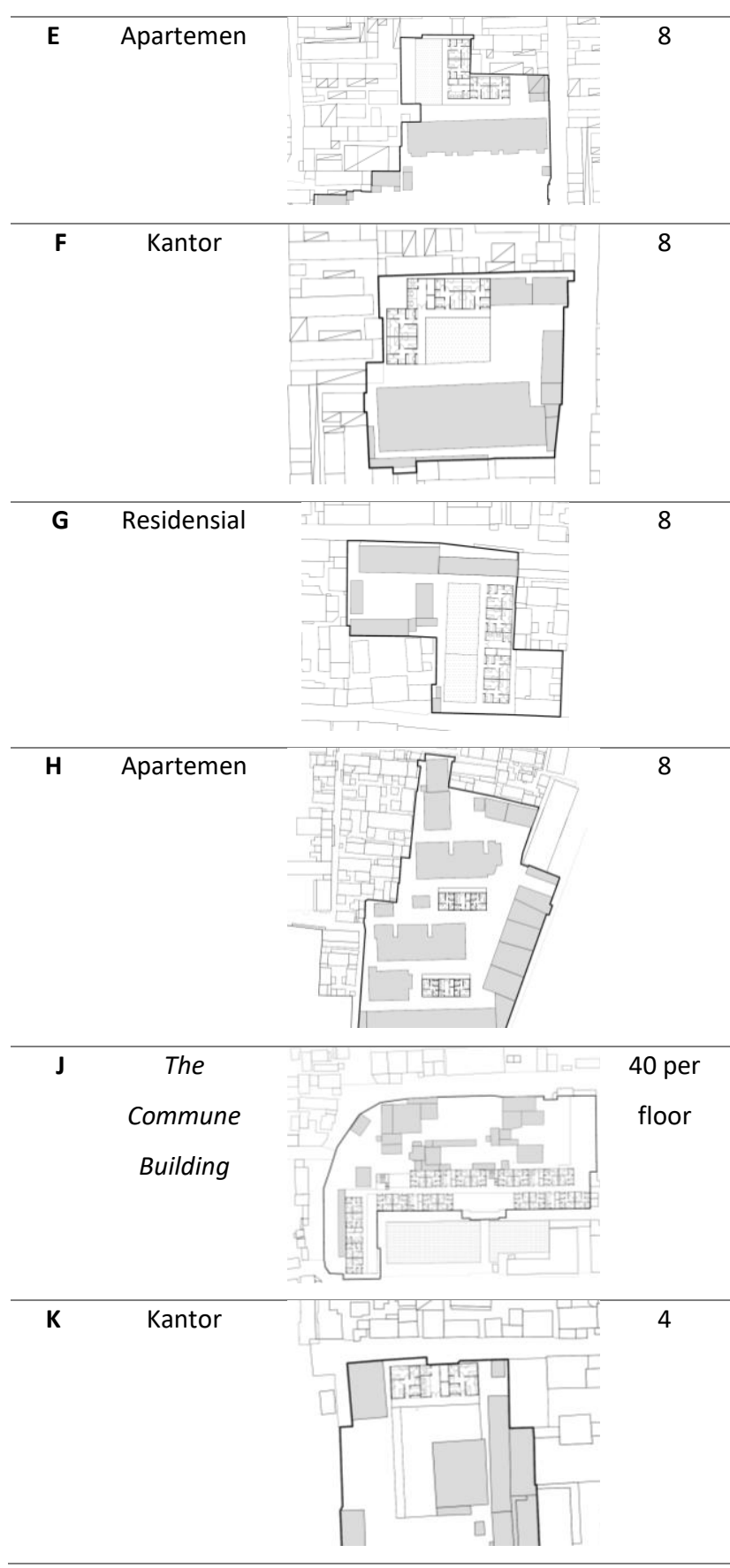

\section{HASIL DAN PEMBAHASAN}

Berdasarkan hasil dari identifikasi sebelumnya terdapat total 9 plot terpilih yang dapat mengakomodasi fungsi PBK. Akan tetapi, meskipun kesembilan plot terpilih ini memenuhi seluruh kriteria identifikasi, tetapi terdapat dua plot yang tidak sesuai dengan 
kondisi tapak bloknya, yaitu Plot $\mathrm{C}$ dan $\mathrm{H}$. Penempatan unit ruang tinggal pada plot ini menimbulkan potensi konflik pada sirkulasi karena ruang kosong yang ada pada plot ini berada di tengah-tengah tapak yang dikelilingi oleh bangunan eksisting sehingga unit ruang tinggal senior dapat terganggu oleh aktivitas sirkulasi dari bangunan residensial eksisting. Berbeda halnya dengan Plot J yang merupakan bangunan terbengkalai setinggi 8 lantai ini, meskipun tidak dapat menyediakan halaman tengah atau courtyard dengan rasio 1:3, tetapi bangunan ini merupakan salah satu bangunan tinggi yang tidak tertutup atau terhalang oleh bangunan lain dengan ketinggian yang sama sehingga akses terhadap sinar matahari dan angin tetap tersedia. Selain itu, pada sisi depan dan belakang bangunan ini juga memiliki lahan kosong yang bisa digunakan sebagai aktivitas sosial baik untuk penghuni senior maupun seluruh penghuni di kawasan White Pagoda. Dengan demikian, Plot J tetap digunakan sebagai salah satu plot terpilih karena aktivitas sosial dan kebutuhan udara serta matahari masih dapat terpenuhi sehingga total plot terpilih berjumlah 7 buah dari 9 plot.

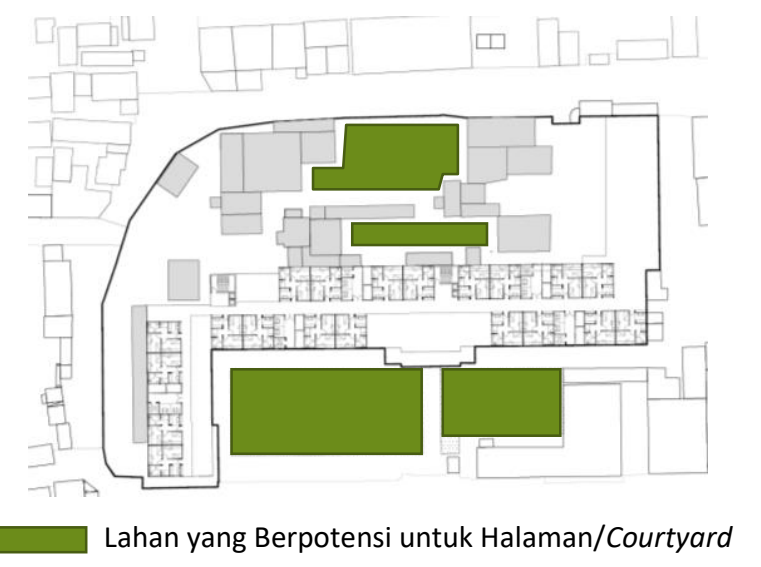

Gambar 7. Potensi Lahan untuk Halaman/Courtyard pada Plot $\mathrm{J}$

(Sumber: White Pagoda Temple Preservation, Renovation and Renewal Plan, 2014)

Selanjutnya, sesuai dengan sistem polisentris PBK maka perawatan pusat (care center) dan penunjang (care stations) ditentukan. Berdasarkan kapasitas lahan dari plot-plot terpilih, maka Plot J sesuai untuk perawatan pusat karena dapat mengakomodasi tempat tidur dengan jumlah terbanyak yaitu 40 tempat tidur atau 20 unit ruang tinggal per lantai dan plot-plot lainnya (Plot A, D, E, F, G, dan K) sebagai perawatan penunjang (care stations). Plot-plot yang berfungsi sebagai perawatan penunjang dapat mengakomodasi total 48 tempat tidur sehingga Plot J menyediakan 234 tempat tidur atau sekitar 5,5 lantai dari total tinggi 8 lantai. Sisa 2,5 lantai ini dapat digunakan untuk fasilitas perawatan. Dengan demikian, sistem polisentris PBK pada Kawasan Tradisional Hutong memiliki Plot J sebagai pusatnya yang memiliki lokasi strategis tepat di tengah kawasan dan didukung oleh plot-plot sekelilingnya seperti yang ditunjukan pada gambar di bawah ini: 


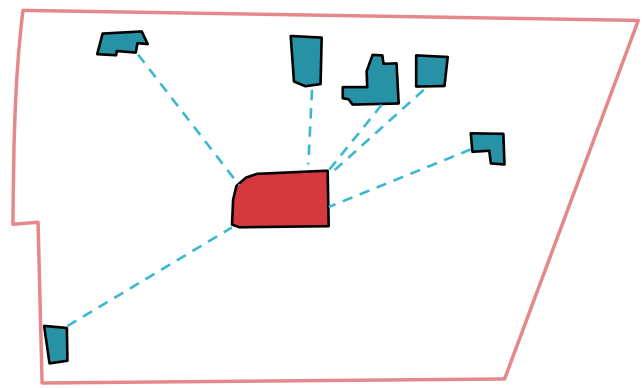

Plot J sebagai Perawatan Pusat (Care Center)

Plot lainnya sebagai Perawatan Penunjang (Care Stations)

Batas wilayah Kawasan White Pagoda

Konektivitas antara Perawatan Pusat dan Penunjang

Gambar 8. Sistem Polisentris PBK pada Kawasan Tradisional White Pagoda

(Sumber: Ilustrasi dari Penulis)

Selanjutnya, mengenai fasilitas perawatan untuk senior Plot J mengakomodasi fasilitas medis, rekreasi (untuk senior yang tinggal di plot tersebut), pelayanan dari rumah ke rumah yaitu catering makanan dan kantor untuk staf administrasi dan perawat serta ruang pelatihan untuk perawat. Fasilitas perawatan ini mengikuti rasio standar dari Pemerintah Beijing yaitu kategori 200 tempat tidur yang disesuaikan untuk 276 tempat tidur seperti yang dapat dilihat pada Tabel 7. Total luas area fasilitas perawatan ini adalah 1,603.56 $\mathrm{m}^{2}$ yang dapat diakomodasi dalam satu lantai bangunan terbengkalai di Plot J yang memiliki luas per lantai 2,503 $\mathrm{m}^{2}$. Dengan demikian, Plot J sebagai perawatan pusat dapat mengakomodasi fasilitas perawatan untuk ke 276 senior dan tidak menutup kemungkinan juga fasilitas ini dapat digunakan oleh senior lain dalam Kawasan Hutong tersebut.
Tabel 3. Luas Fasilitas Perawatan untuk 276 Senior

\begin{tabular}{|c|c|c|c|c|}
\hline $\begin{array}{c}\text { Jenis } \\
\text { Fasilitas }\end{array}$ & Fungsi & $\begin{array}{c}\text { Rasio } \\
200 \\
\text { tempat } \\
\text { tidur } \\
\text { (m2/ } \\
\text { orang) }\end{array}$ & $\begin{array}{l}\text { Luas } \\
\text { (m2) } \\
\text { dengan } \\
\text { kategori } \\
200\end{array}$ & $\begin{array}{c}\text { Luas (m2) } \\
\text { untuk } 276 \\
\text { tempat } \\
\text { tidur }\end{array}$ \\
\hline \multirow[t]{8}{*}{ Medis } & Diagnosa & 0.12 & 240 & 331,2 \\
\hline & ECG & 0.06 & 12 & 16,56 \\
\hline & Lab & 0.09 & 18 & 24,84 \\
\hline & Apotik & 0.09 & 18 & 24,84 \\
\hline & Rehabilitasi & 0.54 & 108 & 149,04 \\
\hline & Konseling & 0.48 & 96 & 132,48 \\
\hline & Ruang Sosial & 0.18 & 36 & 49,68 \\
\hline & Hall & 0.90 & 180 & 248,40 \\
\hline \multirow[t]{4}{*}{ Kantor } & Perawat & 1.04 & 208 & 287,04 \\
\hline & Adminstrasi & 0.40 & 80 & 110,40 \\
\hline & Bisnis & 0.08 & 16 & 22,08 \\
\hline & Training & 0.27 & 54 & 74,52 \\
\hline In-house & Catering & 0.48 & 96 & 132,48 \\
\hline \multirow[t]{2}{*}{ Service } & Makanan & & & \\
\hline & & & Total & $1.603,56$ \\
\hline
\end{tabular}

\section{SIMPULAN}

Sistem PBK mampu mengakomodasi seluruh jumlah tempat tidur yang dibutuhkan beserta fasilitas perawatannya tanpa mengeliminasi bangunan lama dan memindahkan senior ke lingkungan yang baru. Pada penerapan praktis, peletakan fungsi PBK pada plot-plot terpilih memerlukan studi lebih lanjut pada aspek kesehatan dan kenyamanan seperti sirkulasi, ventilasi, dan jarak tempuh berjalan kaki yang nyaman bagi senior. 


\section{DAFTAR PUSTAKA}

Azmi, Diyanah Inani, et all. 2012. Comparing the Walking Behaviour between Urban and Rural Residents. Procedia - Social and Behavioral Sciences Vol. 68: 406416

Bibby, Andrew.2013. Community Ownership of Public Buildings. Retrieved from: https://www.theguardian.com/socialenterprise-

network/2013/jan/17/community-

ownership-public-buildings. [accessed 2018-08-15]

Beijing Institute of Architectural Design. 2013. White Pagoda Temple Preservation, Renovation, and Renewal Plan. BIAD: Beijing

Boermal, Anna. 2006. No Wasting and Empty Nesters: Old Age in Beijing. Oxford Development Studies Vol. 34 No. 4: 401418

Broudehoux, Anne Marie. 1994. Neighborhood Regeneration in Beijing: An Overview of Projects Implemented in the Inner City since 1990. Thesis: School of Architecture, McGill University, California

Chen, Sheying, and Jason L. Powell. 2012. Aging in China: Implications to Social Policy of A Changing Economic State. Springer: New York
Cheng, Yang. 2010. Residential Care for the Elderly People in Beijing, China: A Study of the Relationship Between Health and Place. Journal of Social Science and Medicine Vol. 72: $365-372$

Ministry of Civil Affairs of People's Republic China. 2010. Architecture Standard of Elderly Care (老年美护院建设标准). Beijing: China Planning Press

Moore, Malcolm. 2013. China's Ageing Population: 100-year Waiting List for Beijing Nursing Home. Retrived from https://www.telegraph.co.uk/news/world news/asia/china/9805834/Chinas-ageingpopulation-100-year-waiting-list-for-

Beijing-nursing-home.html. [Accessed 2018-08-18]

Zhang, Donia. 2015. Classical Courtyard Houses of Beijing: Architecture as Cultural Artifact. Journal of Space and Communications, Vol. 1 No. 1: 47-68

Zhang, Hong. 2012. Family Care or Residential Care? The Moral and Practice Dilemmas Facing the Elderly in Urban China. Journal of Asian Anthropology, Vol. 5 No. 1: 57-83

Xu, Qingwen, and Jianguo Gao. 2005. Community Centers in Urban China. Journal of Community Practice, Vol. 13 (3)

Yutaka, Hirako. 2002. Beijing Hutong Conservation Plan. Tibet Heritage Fund International: Beijing 